\title{
Preservasi Sisa Manusia dari All Saints Church Fishergate York, Inggris
}

\author{
Dyah Prastiningtyas \\ Alumunus University of Sheffield Inggris \\ Email : dee.prastiningtyas@gmail.com
}

\begin{abstract}
Abstrak: Situs yang merupakan bekas gereja All Saints yang terletak di area Fishergate (York) ini dapat menjadi contoh situs yang memberikan informasi mengenai tingkat preservasi sisa manusia di wilayah Inggris. Ekskavasi tahun 2007-2008 berhasil menemukan ratusan individu yang digunakan dalam penelitian ini, dibantu dengan metode-metode yang berkaitan dengan statistik untuk mengetahui frekuensi dan indeks preservasi anatomis dari masing-masing individu. Metode-metode ini diharapkan dapat memberinformasi mengenai tingkat representasi dan preservasi elemen rangka serta mendapatkan informasi bagaimana faktor lokasi, periode penguburan, dan kategori usia serta jenis kelamin dapat mempengaruhi tingkat preservasi tersebut.

Tingkat preservasi sisa manusia berkaitan erat dengan faktor-faktor seperti lokasi penguburan, kedalaman penguburan, dan juga usia mati individu yang bersangkutan. Hasil analisis menunjukkan bahwa tulang-tulang panjang seperti tibia dan fibula memiliki tingkat preservasi yang tinggi yang dibutuhkan untuk bertahan dari gejalagejala tafonomi yang terjadi setelah penguburan. Kondisi ini dapat terjadi pada tulang yang berstruktur kuat dan berukuran besar, jika dibandingkan dengan tulang-tulang seperti tulang pergelangan tangan dan kaki, tulang-tulang jari, dan hyoid yang berukuran kecil. Analisis juga menunjukkan bahwa individu yang dikuburkan di areal dalam gereja memiliki tingkat preservasi yang lebih baik jika dibandingkan dengan individu yang dikuburkan di areal luar gereja. Individu-individu pada sampel yang berasal dari periode Romano-British menunjukkan tingkat preservasi yang lebih tinggi. Hal ini berkaitan dengan kedalaman letak kubur dari permukaan tanah. Sementara itu, perbandingan antara usia mati antara individu-individu sampel menunjukkan bahwa sisa individu berusia dewasa terpreservasi lebih baik jika dibandingkan dengan sisa individu yang berusia kanak-kanak. Penelitian mengenai tafonomi sisa manusia ini hanyalah bersifat penelitian tahap awal, sehingga ada baiknya dilakukan penelitian lebih lanjut.
\end{abstract}

Kata Kunci : Situs All Saints Church Fishergate York, preservasi, sisa manusia, tafonomi

\begin{abstract}
The site of All Saints Church, Fishergate have the potential to provide information about skeletal preservation as an issue in human taphonomy. Recent excavations undertaken on this site have unearthed a great number of skeletal remains. By employing methods of frequencies and anatomical preservation index scores it is possible to obtain information about well presented and well preserved skeletal elements, as well as obtaining information of how the factors of location, periods, and age categories relate to the state of preservation of the skeletal elements. Moreover, the obtained results may lead to the interpretation of what sort of factors might have caused the conditions.

The results of analysis from this research show that long limb bones such as tibia and fibula bear a higher level of taphonomical strength which is necessary in order to survive any taphonomical threats. This condition may happen due to the structure of long limb bones as they are more resistant to the threats compared to smaller bones such as hyoid, carpal, and tarsal bones. The state of preservation appears to be related to factors such as location, grave depth (i.e. information of assigned periods, in this research), and age categories. Results show that the remains buried inside the church present a higher state of preservation compared to the remains buried outside the church. The individuals taken as sample in this research show that the remains originated from Roman period also present a higher state of preservation, which is due to the depth of burials of these remains. Lastly, the comparison of adult and juvenile skeletal elements shows that the remains of adult were preserved highly better compared to the juvenile remains. This research has only covered a small part over the broad issues of human taphonomy and further or more detailed researches are highly possible to be established.
\end{abstract}

Keywords : All Saints Church Fishergate York, preservation, skeletal, taphonomy 


\section{A. Latar Belakang}

Tafonomi merupakan sebuah sub-disiplin dari bidang ilmu paleontologi yang mempelajari proses-proses yang terjadi pada benda organik yang mati. Saat ini pendekatan tafonomi mulai umum digunakan dalam konteks arkeologi (Bonnichsen, 1989; Micozzi, 1991; White \& Folkens, 2005). Behrensmeyer \& Kidwell (1985 in Bonnichsen, 1989: 2) mendefinisikan tafonomi (dalam kaitannya dengan konteks arkeologi) sebagai "studi yang berkaitan dengan proses-proses pada preservasi dan bagaimana proses-proses tersebut mempengaruhi fosil." Tujuan mempelajari isu-isu yang berkaitan dengan tafonomi adalah untuk menentukan tahapan-tahapan transformasi pada artefak dan ekofak, serta untuk mengidentifikasikan apakah penyebab transformasi tersebut. Pemahaman mengenai hal ini dapat membantu tahap interpretasi akan interaksi antara temuan sisa manusia dengan konteksnya dalam kubur dan situs itu sendiri. Tafonomi sisa manusia merupakan salah satu isu dalam bidang studi tafonomi yang secara spesifik mempelajari proses-proses tafonomi pada sisa manusia (Bello \& Andrews, 2006: 1; Lieverse, et al., 2006: 1141), dalam hal ini termasuk mengenai preservasi elemen rangka yang selalu berbeda satu dan lainnya.

Perbedaan dalam kondisi preservasi dalam konteks kubur harus menjadi salah satu fokus perhatian dari para arkeolog. Perbedaan ini terjadi berbagai temuan kubur dari berbagai situs, namun dapat pula terjadi pada temuantemuan kubur dalam satu situs yang sama (Henderson, 1987: 43). Tingkat preservasi yang bervariasi antara individu-individu yang ditemukan ini disebabkan oleh berbagai macam hal. Oleh karena itu sangatlah penting untuk menelusuri asal mula dan penyebab-penyebabnya. Secara garis besar, faktor-faktor yang dapat menyebabkan perbedaan tingkat preservasi pada tulang manusia terbagi menjadi faktor fisik, kimia, dan biologi. Faktor-faktor ini dapat terjadi dari dalam struktur tulang tersebut (intrinsik) ataupun dari lingkungan di luarnya (ekstrinsik). Hal-hal yang dapat berperan menjadi agen tafonomi pada sisa manusia antara lain berupa perlakuan pada praktik penguburan, ekskavasi, dan bahkan teknik-teknik yang digunakan untuk menyimpan sisa manusia ini pada koleksi laboratorium (Bello \& Andrews, 2006: 1).

Perubahan bentuk artefak atau ekofak dipengaruhi oleh faktor-faktor seperti ukuran, kedalaman penguburan, iklim, dan musim yang berlangsung di tempat penemuan, serta kondisi tanah tempat benda-benda tersebut terkuburkan (Grant, et al., 2001: 115). Benda yang terkubur akan mengalami perubahan-perubahan yang juga didukung dengan adanya intrusi-intrusi lain yang disebabkan oleh bakteri, keasaman, air, erosi, es, cacing, akar tumbuhan, sinar matahari, jejak unggas, proses pencairan es, dan juga oksidasi (lihat juga White \& Folkens, 2005). Selain daripada itu, aktivitas-aktivitas seperti pencurian, pertambangan, penggunaan lahan, serta ekskavasi arkeologis pun dapat menyebabkan perubahan-perubahan pada benda yang terkubur. Hal-hal ini termasuk dalam perubahan yang disebabkan oleh manusia (Grant, et al., 2001: 114). Ada pula perubahan yang disebabkan oleh karnivor besar seperti anjing yang dapat menggali tanah tempat benda tersebut dikuburkan.

Metode pada tafonomi sisa manusia dapat diaplikasikan pada penelitian yang berkaitan dengan sejarah himpunan fosil (Boaz \& Behrensmeyer, 1976), kondisi sisa manusia dari situs Khuzir-Nuge XIV, Siberia (Lieverse, et al., 2006), preservasi sisa manusia pada pekuburan Abad Pertengahan (Bello \& Andrews, 2006), atau pada contoh kasus yang lebih resen seperti pada situs arkeologi Oneida di New York (Nawrocki, 1995).

Sedikit tentang latar belakang situs dan kenapa dapat dipilih menjadi titik berat penelitian. Karena jumlah temuannya yang banyak dan tersebar hampir di seluruh area situs, sehingga diharapkan dapat menggambarkan keberagaman tingkat preservasi dari individu sampel yang digunakan dalam analisis.

\section{B. Permasalahan dan Tujuan Penelitian}

Permasalahan penelitian ini menitikberatkan pada kaitan antara tingkat preservasi pada individu sampel dengan lingkungan di sekitarnya. Pertanyaan-pertanyaan penelitian yang dilakukan pada All Saints Church di kota York, Inggris juga diharapkan dapat memberikan gambaran dan penjelasan mengenai kondisi dan tingkat preservasi sisa manusia yang ditemukan. Sampel-sampel yang diambil dan metode analisis yang dilakukan untuk membantu menjelaskan permasalahan tersebut, serta dapat pula menelusuri penyebab bermacam proses tafonomi yang terjadi pada temuan-temuan tersebut. Pertanyaan-pertanyaan penelitian yang diajukan antara lain adalah:

a. Tingkat preservasi apa sajakah yang dapat diamati pada sampel individu yang ditemukan di situs All Saints Church of Fishergate, York?

b. Elemen rangka apa saja yang paling banyak ditemukan dan dari jenis tulang seperti apa, serta bagaimana penjelasannya?

c. Apakah tingkat preservasi sisa manusia bervariasi terhadap usia mati dan keletakan temuan tiap individunya?

d. Faktor-faktor apa sajakah yang dapat mempengaruhi perbedaan pada tingkat preservasi di antara individuindividu yang menjadi sampel dalam penelitian ini? 
Tujuan penelitian ini adalah untuk mengidentifikasi perbedaan preservasi permukaan tulang dari suatu himpunan sisa manusia, serta mengetahui bentuk dan pola perbedaan preservasi dari koleksi yang didapat dari situs All Saints Church Fishergate, York.

\section{Materi Penelitian}

Jumlah seluruh sisa manusia yang ditemukan di situs ini adalah 580 individu, yang berasal dari pembabakan masa Abad Pertengahan dan RomanoBritish. Pertama kali situs ini dibuka, sisa manusia yang ditemukan diduga berasal dari korban wabah yang tercatat pernah terjadi di wilayah York pada tahun 1604 dan 1631 (Bruce \& McIntyre, 2008). Sementara itu, populasi individu yang dikuburkan di wilayah ini didominasi oleh individu berjenis kelamin laki-laki baik yang berusia remaja hingga berusia paruh baya.

\section{Metode Penelitian}

Metode pengambilan sampel dalam penelitian ini digunakan untuk memperkecil jumlah data yang ada. Sampel-sampel yang dipilih diharapkan dapat merepresentasikan keseluruhan kondisi sisa manusia yang ditemukan di situs ini. Jumlah sampel yang digunakan dalam penelitian ini adalah 100 individu yang dilengkapi dengan informasi mengenai usia dan jenis kelamin yang telah didapat melalui analisis awal yang dilakukan di University of Sheffield. Secara umum, kelompok sisa manusia yang ditemukan di situs ini dibagi menjadi dua kategori lokasi penguburan, yaitu sisa manusia yang dikuburkan di bagian dalam gereja (di dalam gedung) dan sisa manusia yang dikuburkan di bagian luar gereja (halaman gereja). Denah situs yang dilengkapi dengan posisi keletakan temuan sisa manusia digunakan dalam penelitian ini untuk mengetahui sebaran dan keletakan mutlak dari sampel-sampel yang dipakai. Teknik pengambilan sampel dilakukan dengan memilih nomor katalog rangka secara acak dari kedua lokasi, di dalam dan di luar dinding gereja.

Sisa manusia yang diekskavasi pada situs ini dibagi ke dalam tiga periode yang didapatkan dari pertanggalan relatif, yaitu dengan melihat bentuk penguburan, kedalaman kubur dan juga artefak-artefak di sekitarnya. Ketiga periode tersebut adalah Roman, periode awal Abad Pertengahan, dan periode Abad Pertengahan (Bruce, pers. comm., 2009). Dalam kelompok sampel yang diambil, terdapat 6 individu yang berasal dari periode Roman, 7 individu dari periode awal Abad Pertengahan, dan 87 individu dari periode Abad Pertengahan.

Metode-metode yang digunakan untuk mengestimasi usia mati individu sampel adalah dengan mengamati fitur-fitur pada bagian ujung tulang rusuk (sternal ends) (Iscan \& Loth, 1986), mengamati fitur pada auricular surface yang terletak di tulang pinggul (pelvis) (Lovejoy, et al., 1985; Buckberry \& Chamberlain, 2002), dan mengamati keausan permukaan gigi (dental occlusal surface wear) (Miles, 1962). Individu-individu pada sampel terbagi menjadi 18 individu remaja, 79 individu dewasa, dan tiga individu yang tidak diketahui usianya.

Metode-metode yang digunakan untuk menentukan jenis kelamin individu sampel pada penelitian ini adalah berdasarkan metode yang diajukan oleh Brooks dan Suchey (1990), serta menggunakan penentuan jenis kelamin berdasarkan karakterisik morfologi rangka (McIntrye, pers. comm., 2009). Individu-individu pada sampel terdiri dari 35 individu perempuan, 33 individu laki-laki, and 32 individu yang tidak diketahui jenis kelaminnya.

\section{E. Pembahasan}

Rangkaian analisis dilakukan dengan menghitung frekuensi kemunculan dari setiap elemen rangka yang ada. Tahap ini diharapkan untuk menjawab pertanyaan mengenai elemen rangka apa saja yang paling dominan muncul pada sampel temuan. Kemunculan elemen rangka tersebut akan menunjukkan bahwa elemen itu memiliki tingkat preservasi yang baik untuk dapat ditemukan pada ekskavasi, dengan asumsi bahwa elemen rangka yang memiliki kondisi preservasi lebih baik akan muncul lebih sering dalam sebuah sampel.

Berdasarkan analisis yang dilakukan, mandibula $(\mathrm{n}=38)$ merupakan elemen rangka yang paling sering muncul dari sampel tulang kranial, diikuti dengan tulang tempurung kepala $(\mathrm{n}=35)$, dan maxilla $(\mathrm{n}=27)$. Hal ini menunjukkan bahwa tingkat preservasi pada elemen mandibula lebih tinggi daripada tulang tempurung kepala dan maxilla, meskipun elemen tersebut ditemukan dalam kondisi fragmentaris.

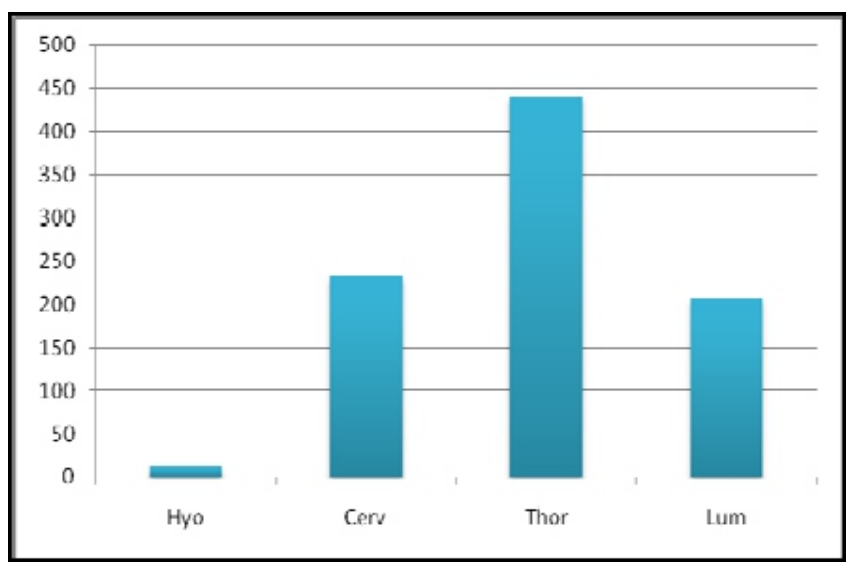

Figur 1. Frekuensi elemen tulang bagian thorax. 
Hyoid ( $\mathrm{n}=13)$ merupakan elemen rangka yang paling sedikit ditemukan, jika dibandingkan dengan tulang-tulang pembentuk tulang punggung (cervical, $\mathrm{n}=233$, thoracic, $\mathrm{n}=441$, dan lumbar, $\mathrm{n}=206$ ) (Figur 1). Tulang punggung bagian thoracic dapat muncul secara dominan karena jumlahnya paling banyak dalam rangkaian tulang-tulang pembentuk tulang punggung, meskipun dari segi bentuk dan ukuran tulang punggung bagian lumbar merupakan tulang yang paling besar dan berstruktur lebih tebal dan kompak jika dibandingkan dengan tulang-tulang pembentuk tulang punggung lainnya. Sementara itu byoid berada pada tingkat kemunculan paling kecil yang disebabkan oleh ukurannya yang kecil dan bentuknya yang mudah hancur. Begitu juga halnya dengan tulang rusuk ( $\mathrm{n}=770$ ) yang muncul dengan angka tinggi jika dibandingkan dengan tulang-tulang bagian thorax lainnya. Rangkaian tulang rusuk yang berjumlah banyak membuat bias pada jumlah ini sangat besar.

Pada bagian tulang-tulang anggota tubuh atas radius $(\mathrm{n}=90)$ dan ulna $(\mathrm{n}=91)$ merupakan elemen rangka yang paling sering muncul, namun frekuensi ini tidak menunjukkan perbedaan yang signifikan jika dibandingkan dengan elemen rangka pada tulang anggota tubuh lainnya (Figur 2). Dalam rangkaian tulang pembentuk pergelangan tangan serta tulang-tulang jari tangan, tulang telapak tangan muncul paling sering dalam sampel temuan ( $\mathrm{n}=328)$, diikuti dengan tulang jari tangan $(\mathrm{n}=254)$ dan tulang pergelangan tangan $(\mathrm{n}=242)$.
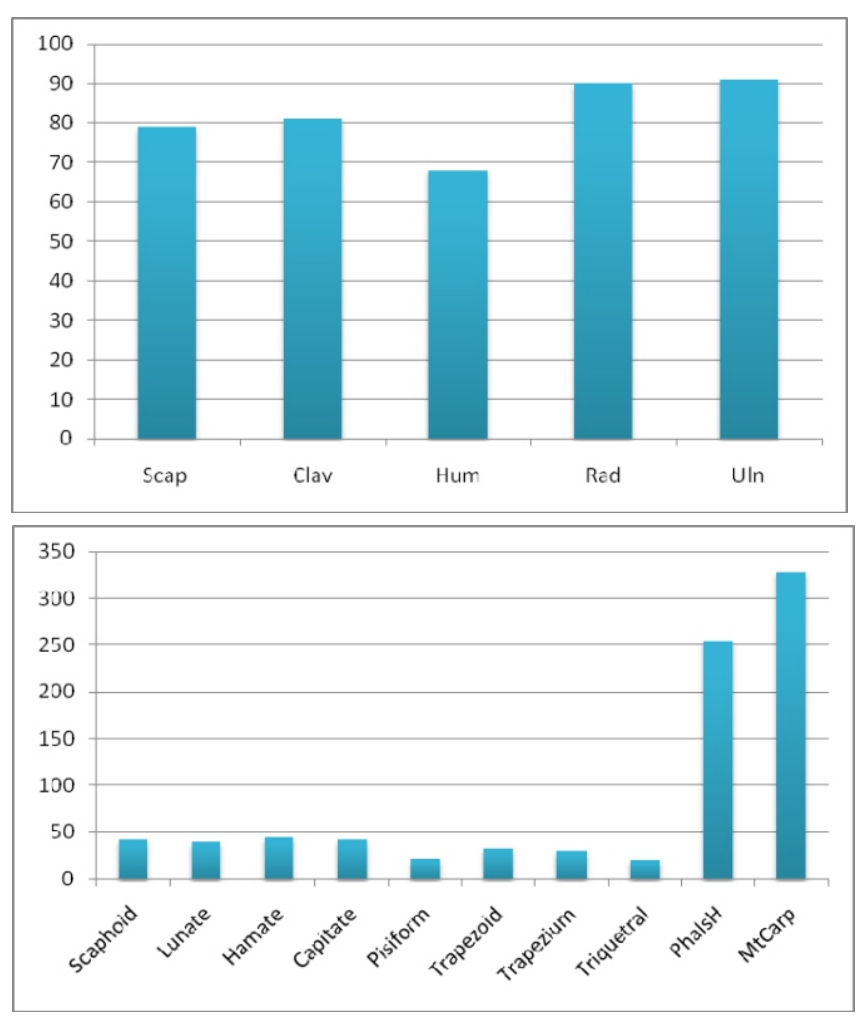

Figur 2. Frekuensi elemen tulang anggota tubuh atas
Namun, tulang-tulang pada rangkaian ini tidak seluruhnya ditemukan dalam keadaan lengkap. Secara mendetil, angka kemunculan pada tulang pergelangan tangan adalah sebagai berikut, hamate $(\mathrm{n}=45)$, capitate $(\mathrm{n}=42)$, scaphoid $(\mathrm{n}=42)$, dan lunate $(\mathrm{n}=40)$ merupakan elemen rangka yang paling sering muncul dalam rangkaian ini, sementara pisiform $(\mathrm{n}=22)$ dan triquetral $(\mathrm{n}=20)$ merupakan elemen rangka yang paling jarang muncul.

Frekuensi kemunculan tulang pinggul $(\mathrm{n}=74)$ lebih banyak dibandingkan dengan tulang duduk (sacrum) $(\mathrm{n}=41)$. Hal ini dapat terjadi karena struktur tulang pinggul yang lebih kompak daripada sacrum, meskipun tulang pinggul ditemukan dalam kondisi fragmentaris.

Frekuensi tulang panjang pada kelompok anggota tubuh bawah tidak memperlihatkan perbedaan yang signifikan. Tibia $(\mathrm{n}=136)$ dan fibula $(\mathrm{n}=134)$ nampak sebagai elemen tulang yang paling sering muncul, diikuti oleh femur $(\mathrm{n}=117)$. Sementara itu, patella merupakan elemen rangka yang paling jarang muncul $(\mathrm{n}=66)$ dalam kelompok ini.

Elemen rangka yang memiliki tingkat preservasi tinggi muncul pada sampel-sampel berupa mandibula, vertebra thoracic, tulang rusuk, radius, ulna, tulang pergelangan tangan, tulang telapak tangan, tulang pinggul, tibia, fibula, tulang telapak kaki, dan beberapa tulang pergelangan kaki. Elemen rangka yang memiliki preservasi lebih rendah muncul pada sampel yang berupa maxilla, byoid, sternum, bumerus, sacrum, femur, cuboid, dan navicular. Sementara itu, elemen-elemen rangka lain termasuk ke dalam kategori tulang-tulang yang memiliki tingkat preservasi cukup baik, dengan frekuensi kemunculan yang banyak, namun tidak dominan pada sampel.

Kemunculan tulang-tulang panjang seperti tibia dan fibula pada sampel ini menunjukkan bahwa faktor ukuran dan struktur tulang sangatlah penting dalam menentukan tingkat preservasinya. Hal ini berkaitan dengan komposisi tulang-tulang tersebut yang termasuk ke dalam tulang kortikal. Namun demikian, femur yang strukturnya jauh lebih kompak dibandingkan dengan fibula, tidak muncul sebagai elemen rangka yang dominan ditemukan. Hal ini dapat terjadi mengingat penggunaan lahan yang terjadi berkali-kali pada sejarah situs tersebut, sehingga dapat saja tulang itu terpotong hingga ke tingkat fragmentasi yang tinggi dan teraduk. Tulang-tulang yang berukuran kecil seperti byoid, tulang-tulang jari, dan lainnya secara konsisten muncul sebagai elemen tulang yang jarang ditemukan. Hal ini juga berkaitan dengan komposisi tulang-tulang tersebut yang termasuk dalam kategori tulang trabekular. Tulang-tulang dalam kategori trabekular lebih cepat terurai setelah penguburannya, karena 
kepadatan tulang lebih kecil dibandingkan dengan tulangtulang dalam kategori tulang kortikal. Tulang berukuran kecil dapat dengan mudah berpindah tempat yang disebabkan adanya pergerakan dari aktivitas bawah tanah seperti cacing dan roden. Selain daripada itu, struktur tulang yang berukuran kecil sangat memungkinkan bagi tulang tersebut untuk hancur lebih cepat dibandingkan dengan tulang dengan struktur yang lebih kompak. Kembali mengingat penggunaan lahan dalam sejarah situs ini, membuat tulang-tulang kecil lebih mudah untuk hilang dalam proses tersebut. Prosedur ekskavasi yang tidak berhati-hati pun dapat menyebabkan tulang-tulang ini tidak terdeteksi dan hilang.

Analisis indeks preservasi anatomis yang dilakukan dengan membandingkan frekuensi tulang yang ditemukan dengan lokasi penemuannya menunjukkan bahwa tulangtulang yang berasal dari individu-individu yang ditemukan di bagian dalam gereja terpreservasi lebih baik daripada tulang-tulang dari individu yang ditemukan di bagian luar gereja. Hal ini jelas sekali menunjukkan bahwa kondisi tanah di bagian dalam gereja lebih baik sebab terlindungi oleh dinding bangunan tersebut. Pada bagian dalam dinding gereja, sisa manusia lebih terlindung dari faktorfaktor seperti pergerakan akar tumbuhan, resapan air, dan aktivitas fauna. Sebaliknya, pada penguburan yang terletak di luar dinding gereja faktor-faktor tersebut dengan leluasa dapat menyebabkan perubahan bentuk dan percepatan proses hancurnya sisa manusia. Preservasi dengan tingkat tinggi ini menyebabkan elemen-elemen rangka tersebut tinggi frekuensi penemuannya.

Analisis indeks preservasi anatomis yang dilakukan dengan membandingkan frekuensi tulang yang ditemukan dengan periodisasi penguburan menunjukkan bahwa meskipun jumlah keseluruhan individu dari periode Abad Pertengahan lebih banyak daripada individu dari periode Roman, tulang-tulang yang berasal dari periode Roman ini memiliki tingkat preservasi yang lebih tinggi daripada tulang-tulang yang berasal dari periode Abad Pertengahan. Hasil ini berkaitan dengan cara penguburan pada periode Roman yang lazimnya meletakkan sisa manusia pada kubur yang cukup dalam sehingga terlindungi dari proses transformasi kultural yang bersifat menghancurkan, meskipun situs ini telah digunakan berkali-kali. Kubur dengan kedalaman yang tidak signifikan lebih mudah terintrusi oleh kegiatan-kegiatan pengolahan dan penggunaan lahan. Oleh sebab itu, elemen rangka pun dapat terganggu preservasinya.

Faktor usia kematian individu nampak menjadi faktor penting dalam menentukan tingkat preservasi elemen rangka. Hasil analisis menunjukkan bahwa individu berusia dewasa muncul dengan tingkat preservasi yang lebih tinggi jika dibandingkan dengan individu yang berusia remaja ataupun kanak-kanak. Struktur, bentuk, serta ukuran tulang pada individu dewasa lebih kompak dan besar dibandingkan dengan tulang pada individu remaja. Proses penghancuran tulang lebih cepat terjadi pada tulang kanak-kanak (Gordon \& Buikstra, 1981), serta dibutuhkan ketelitian yang tinggi untuk mengenali tulang kanak-kanak ini dalam proses ekskavasi. Apabila hal terakhir tersebut gagal dilakukan, maka sangat besar kemungkinan bagi tulang-tulang tersebut untuk terbuang (lihat juga Scheuer \& Black, 2000). Sama halnya dengan tulang individu dewasa yang berukuran kecil, tulang kanak-kanak pun tergolong ke dalam kelompok tulang yang dengan mudah dapat berpindah tempat akibat aktivitas bawah tanah yang disebabkan oleh cacing, roden, dan pergerakan akar tumbuhan (Buckberry, 2000). Beberapa sampel kanak-kanak yang masih dapat terpreservasi dengan baik berkorelasi dengan keletakannya dan kondisi tanah penguburan dengan keasaman rendah.

\section{F. Kesimpulan}

Proses tafonomi yang terjadi pada tinggalantinggalan arkeologis dapat disebabkan oleh dua faktor yaitu faktor alam dan faktor budaya. Dengan mengenali faktor-faktor ini pada gejala yang diamati di lapangan atau pada data yang direkam, seorang peneliti dapat menentukan bagaimana dan mengapa faktor-faktor ini dapat mempengaruhi tingkat preservasi suatu tinggalan arkeologis. Tafonomi sisa manusia, yang berfokus pada data berupa tulang-tulang dan gigi sebagai tinggalan arkeologis, berusaha untuk menjelaskan pertanyaanpertanyaan yang berkaitan dengan proses penguburan dan proses lain yang terjadi setelah penguburan hingga sisa manusia itu ditemukan. Pentingnya mengetahui tingkat preservasi tinggalan sisa manusia ini adalah berkaitan dengan perencanaan kelangsungan kegiatan ekskavasi dan juga berkaitan dengan perencanaan proses analisis lanjutan yang akan dilakukan setelah kegiatan ekskavasi berakhir, karena akan berkaitan dengan metode analisis apa yang akan digunakan. Hal ini juga berguna untuk mempersiapkan tahapan-tahapan konservasi sisa manusia itu sendiri. (Micozzi, 1995 ; Bonnichsenm 1989)

Dari seluruh faktor tafonomi yang terjadi pada sisa manusia di situs ini, faktor yang dianggap paling mempengaruhi tingkat preservasi elemen rangka adalah penggunaan dan pengolahan lahan yang berulang kali terjadi sehingga menyebabkan terganggunya preservasi elemen-elemen tersebut. Dalam sejarahnya, tidak hanya sekali wilayah bekas All Saints Church Fishergate ini digunakan oleh penduduk sekitar, bahkan hingga saat ini. 
Proses pembersihan lahan yang terjadi pada tahun 2007 berkaitan dengan rencana pembangunan gedung tepat di atas situs All Saints Church menyebabkan terpotongnya elemen rangka. Penelitian lebih lanjut dapat dilakukan dengan mempertimbangkan faktor-faktor lain seperti faktor intrinsik berupa kondisi patologis individu-individu yang ditemukan, karena penyakit yang diderita dapat mengubah struktur di dalam tulang yang tentunya akan mempengaruhi pula pada tingkat preservasinya. Faktor tafonomi lain yang berupa tingkat fragmentasi tulang dapat pula dijadikan topik penelitian lanjutan yang dapat memberikan informasi mengapa individu-individu ini dikuburkan di area All Saints Church Fishergate York.

\section{Daftar Pustaka}

Adams, B.J. \& Konigsberg, L.W. 2004. Estimation of the Most Likely Number of Individuals from Commingled Human Skeletal Remains. American Journal of Physical Anthropology 125: 138-151.

Andrews, P. \& Cook, J. 1985. Natural Modification to Bones in a Temperate Setting. Man 20(4): 675691.

Andrews, P. \& Bello, S. 2006. Pattern in Human Burial Practice. In Gowland, R. \& Knüsel, C. (eds) Social Archaeology of Funerary Remains, 14-29. Oxford: Oxbow Books.

Behrensmeyer, A.K. 1978. Taphonomic and Ecologic Information from Bone Weathering. Paleobiology 4: 150-162.

Bell, L.S. \& Elkerton, A. 2008. Unique Marine Taphonomy in Human Skeletal

Material Recovered from the Medieval Warship Mary Rose. International Journal of Osteoarchaeology 18: 523-535.

Bello, S., Thomann, A., Massa, E.R., \& Dutour, O. 2003. Quantification de l'état de conservation des collections ostéoarchéologiques et ses champs d'application en anthropologie. Anthropo 5: 2137. Available at www.didac.ehu.es/antropo

Bello, S.M., Thomann, A., Signoli, M., Dutour, O., \& Andrews, P. 2006. Age and Sex Bias in The Reconstruction of Past Population Structures. American Journal of Physical Anthropology 129: 24-38.

Bello, S. \& Andrews, P. 2006. The intrinsic pattern of preservation of human skeletons and its influence on the interpretation of funerary behaviours. In Gowland, R. \& Knüsel, C. (eds) Social Archaeology of Funerary Remains, 1-13. Oxford: Oxbow Books.

Boaz, N.T. \& Behrensmeyer, A.K. 1976. Hominid Taphonomy: Transport of Human Skeletal Parts in an Artificial Fluviatile Environment. American Journal of Physical Anthropology45: 53-60.
Boddington, A., Garland, A.N., \& Janaway, R.C. (eds.) 1987. Death, Decay, and Reconstruction: Approaches to archaeology and forensic science. Manchester University Press: Manchester.

Bonnichsen, R. 1989. An Introduction to Taphonomy with an Archaeological Focus. In Bonnichsen, R. \& Sorg. M.H. (eds.) Bone Modification, 1-5. Dexter, MI,USA: Thompson-Shore, Inc.

Boyle, A., Boston, C. \& Witkin, A. 2005. The Archaeological Experience at St Luke's Church Old Street, Islington. Oxford Archaeology.

Brickley, M. \& McKinley, J.I. 2004. Guidelines to the Standards for Recording Human Remains. Institute of Field Archaeologists Paper No. 7. BABAO.

Brooks, S.T. \& Suchey, J.M. 1990. Skeletal age determination based on the os pubis: a comparison of the Asca'di-Nemeske'ri and Suchey-Brooks methods. Human Evolution 5: 227-238.

Brothwell, D. 1981. Digging Up Bones. Cornell University Press: New York.

Buckberry, J.L. \& Chamberlain, A.T. 2002. Age estimation from the auricular surface of the ilium: a revised method. American Journal of Physical Anthropology 119: 231-239.

Buikstra, J.E. \& Ubelaker, D.H. (eds) 1994.Standards for Data Collection from Human Skeletal remains. Fayetteville: Arkansas Archaeological Survey Research Series No. 44.

Collins, M.J., Nielsen-Marsh, C.M., Hiller, J., Smith, C.I. \& Roberts, J.P. 2002. The Survival of Organic Matter in Bone: A Review. Archaeometry 44(3): 383-394.

Denys, C. 2002. Taphonomy and Experimentation. Archaeometry 44(3): 469-484.

Dirkmaat, D.C., Cabo, L.L., Ousley, S.D. \& Symes, S.A. 2008. New Perspective in Forensic Anthropology. Yearbook of Physical Anthropology 51: 33-52. 
Dodson, P. \& Wexlar, D. 1979. Taphonomic Investigations of Owl Pellets. Paleobiology 5(3): 275-284.

Dominguez-Solera, S.D. \& Dominguez-Rodrigo, M. 2009. A Taphonomic Study of Bone Modification and of Tooth-Mark Patterns on Long Limb Bone Portions by Suids. International Journal of Osteoarchaeology 19: 345-363.

Drennan, R. D. 1996. Statistics for Archaeologists. New York: Plenum Press. Garland, A.N., Janaway, R.C. \& Roberts, C.A. 1988. A Study of The Decay Processes of Human Skeletal Remains from The Parish Church of the Holy Trinity, Rothwell, Northamptonshire. Oxford Journal of Archaeology 7(2): 235-252.

Gordon, C.C. \& Buikstra, J.E. 1981. Soil pH, Bone Preservation, and Sampling Bias at Mortuary Sites. American Antiquity 46(3): 566-571.

Götherström, A., Collins M.J., Angerbjörn, A. \& Líden, K. 2002. Bone Preservation and DNA Amplification. Archaeometry 44(3): 395-404.

Grant, J., Gorin, S. \& Fleming, N. 2001. The Archaeology Coursebook, An Introduction to Themes, Sites, Methods, and Skills. London: Routledge.

Hedges, R.E.M. 2002. Bone Diagenesis: An Overview of Processes. Archaeometry 44(3): 319-328.

Henderson, J. 1987. Factors Determining The State of Preservation of Human Remains. In Boddington, A., Garland, A.N. \& Janaway, R.C. (eds.). Death, Decay, and Reconstruction: Approaches to archaeology and forensic science, 43-54. Manchester: Manchester University Press.

Hill, Andrew. 1979. Butchery and Natural

Disarticulation: An Investigatory Technique.

American Antiquity 44(4): 739-744.

Janaway, R.C. 1987. The preservation of organic materials in association with metal artifacts deposited in inhumation graves. In Boddington, A., Garland, A.N., \& Janaway, R.C. (eds), Death, Decay, and Reconstruction. pp. 127-148. Manchester: Manchester University Press.

Jans, M.M.E. \& Kars, H. 2002. In situ Preservation of Archaeological Bone: A Histological Study Within a Multidisciplinary Approach. Archaeometry 44(3): 343-352.

King, T., Andrews, P. \& Boz, B. 1999. Effect of Taphonomic Processes on Dental Microwear. American Journal of Physical Anthropology 108: 359-373.

Klippel, W.E., Synstelien, J.A. 2007. Rodents as
Taphonomic Agents: Bone Gnawing by Brown Rats and Gray Squirrels. Journal of Forensic Science 52(4): 765-773.

Lieverse, A.R., Weber, A.W. \& Goriunova, O.I. 2006. Human Taphonomy at Khuzhir-Nuhe XIV, Siberia: a new method for documenting skeletal condition. Journal of Archaeological Science 33: 1141-1151.

Lovejoy, C.O., Meindl, R.S., Pryzbek, T.R., \& Mensforth, R.P. 1985. Chronological

metamorphosis of the auricular surface of the ilium: a new method for the determination of adult skeletal age at death. American Journal of Physical Anthropology 86: 15-28.

Marshall, L. 1989. Bone Modification and "The Law of Burial”. In Bonnichsen, R.1989. An Introduction to Taphonomy with an Archaeological Focus. In Bonnichsen, R. \& Sorg. M.H. (eds.) Bone Modification. pp. 7-24. Dexter, MI, USA: Thompson-Shore, Inc.

Martin, R.E. 1999. Taphonomy: A Process Approach. Cambridge: Cambridge University Press.

Mays, S. 1998. The Archaeology of Human Bones. Oxon: Routledge.

McIntyre, L. \& Chamberlain, A. T. 2008. York Barbican - The Medieval cemetery of All Saints Church Fishergate, 11th-16th century. Available online at http://www.shef.ac.uk/archaeology/research/ba rbican/ Accessed on May 19th, 2009.

Micozzi, M.S. 1991. Postmortem Change in Human and Animal Remains. Springfield, USA: Charles C. Thomas Publisher.

Milner, G.R. \& Smith, V.G. 1989. Carnivore Alteration of Human Bone From a Late Prehistoric Site in Illinois. American Journal of Physical Anthropology 79: 43-49.

Nakahashi, T. \& Nagai, M. 1986/1987. Preservation of human bone in prehistoric and historic sites of Japan. Asian Perspectives 27(1): 15-27.

Nawrocki, S.P. 1991. Human taphonomy and historic cemeteries: Factors influencing the loss and subsequent recovery of human remains. University of Indianapolis Archaeology \& Forensics Laboratory. Available online at http:/ / archlab.uindy.edu. Accessed on May 1st, 2009.

Nawrocki, S.P. 1995. Taphonomic Processes in Historic Cemeteries. In Grauer, A.L. Bodies of Evidence: Reconstructing History Through Skeletal Analysis, pp. 49-66. New York: John Wiley and Sons. 
Naylor, John. 2001. York and Its Region in the 8th and 9th Centuries AD: An Archaeological Study. Oxford Journal of Archaeology 20(1): 79-105.

Nelson, A.J. 1998. Wandering Bones: Archaeology, Forensic Science and Moche Burial Practices. International Journal of Osteoarchaeology 8: 192-212.

Page, William (ed). 1974. 'Houses of Benedictine monks: Priory of All Saints, Fishersgate', A History of the County of York: Volume 3, pp. 106-107. URL: http://www.britishhistory.ac.uk/report.aspx?compid=36220 Date accessed: 06 September 2009

Roksandic, Mirjana. 2002. Position of Skeletal Remains as a Key to Understanding Mortuary Behavior. In Haglund, W.D \& Sorg, M.H. (eds) Advances in Forensic Taphonomy: Method, Theory, and Archaeological Perspectives, pp. 99-117. Boca Raton: CRC Press.

Scheuer, L. \& Black, S. 2000. Developmental Juvenile Osteology. London: Academic Press Ltd.

Schiffer, M.B. 1983. Toward the Identification of Formation Processes. American Antiquity 48(4): 675-706.

Schwartz, J.H. 1995. Skeleton Keys, an Introduction to Human Skeletal Morphology, Development, and Analysis. New York: Oxford University Press.

Shennan, Stephen. 1997. Quantifying Archaeology. 2nd Edition. Edinburgh: Edinburgh University Press.
Stojanowski, C.M., Seidemann, R.M. \& Doran, G.H. 2002. Differential Skeletal Preservation at Windover Pond: Causes and Consequences. American Journal of Physical Anthropology 119: 15-26.

Trueman, C.N. 2002. The Long-Term Survival of Bone: The Role of Bioerosion. Archaeometry 44(3): 371-382.

Waldron, T. 1987. The Relative Survival of the Human Skeleton: Implications for palaeopathology. In Boddington, A., Garland, A.N. \& Janaway, R.C. (eds.). Death, Decay, and Reconstruction: Approaches to archaeology and forensic science, pp. 55-64. Manchester: Manchester University Press.

Walker, P.L., Johnson, J.R. \& Lambert, P.M. 1988. Age and Sex Biases in the Preservation of Human Skeletal Remains. American Journal of Physical Anthropology 76: 183-188.

White, T.D. \& Folkens, P.A. 2005. The Human Bone Manual. London: Elsevier Academic Press.

Willey, P., Galloway, A. \& Snyder, L. 1997. Bone Mineral Density and Survival of Elements and Element Portions in The Bones of the Crow Creek Massacre Victims. American Journal of Physical Anthropology 104: 513-528. 